\title{
Monika Szewczyk*
}

\section{WYKORZYSTANIE ODNAWIALNYCH ŹRÓDEŁ ENERGII NA PRZYKLADZIE FIRMY IKEA}

\section{THE USE OF RENEWABLE ENERGY IN THE EXAMPLE OF IKEA COMPANY}

\begin{abstract}
The article aims to show the importance of renewable energy sources in the modern economy and demonstrates that investment in unconventional energy may become an integral part of the business. Shows also the main benefits but also the costs of the use of renewable energy sources. The article presents the amount of energy produced from renewable sources in the European Union and selected countries. It shows also the use of renewable energy sources in the example of IKEA. It can become part of management in the company, which also forms part of the concept of corporate social responsibility. The article presents the objectives and activities of the company on the way to achieving energy independence and efficiency in this area.
\end{abstract}

Keywords: renewable energy, corporate social responsibility

JEL classification: M20, M14, O13, Q20, Q25

\section{Wstęp}

Nieodwracalne zmiany klimatyczne i problemy środowiskowe coraz bardziej wpływają na życie społeczne i gospodarcze. Instytucje ponadnarodowe oraz władze państw szukają rozwiązań mogących zniwelować niekorzystne zmiany. Rozwój odnawialnych źródeł energii (OZE) staje się nadzieją na częściowe rozwiązanie problemów. Szczególne wyzwanie stawia się przed światem biznesu i przedsiębiorstwami. Poprzez uwzględnienie aspektów środowiskowych w swojej działalności mogą one znacznie przyczynić się do poprawy sytuacji.

Artykuł przedstawia wykorzystanie odnawialnych źródeł energii na przykładzie firmy IKEA. Prezentuje korzyści i koszty inwestowania w OZE,

* Studentka, SKN Ekobiznes, Wydział Ekonomiczno-Socjologiczny, Uniwersytet Łódzki, e-mail: szewczyk.monikaa@gmail.com. 
ze szczególnym uwzględnieniem energii wiatru i słońca. Przedstawia także wykorzystywanie i inwestycje w OZE jako część zarządzania firmy, wdrażaną poprzez koncepcję społecznej odpowiedzialności biznesu. Praca pokazuje również działalność firmy IKEA w tym obszarze oraz konkretne działania mające pozytywny wpływ na wydajność energetyczną.

\section{Odnawialne źródła energii - istota, pojęcie}

W perspektywie nieodwracalnych zmian klimatycznych, zjawiska kurczenia się zasobów, ocieplania się klimatu i narastającego zanieczyszczenia środowiska naturalnego poszukuje się alternatywnych rozwiązań we wszystkich sektorach życia społeczno-gospodarczego. Odpowiedzią na potrzeby coraz bardziej konkurencyjnej gospodarki i wymagającego rynku jest koncepcja zrównoważonego rozwoju. Rozwój taki określany jest jako „proces zmian, w którym eksploatacja zasobów, kierunki inwestowania, kierunki postępu technicznego i zmiany instytucjonalne pozostają w harmonii i zachowują bieżąco i na przyszłość możliwości zaspokojenia ludzkich potrzeb i aspiracji"1.

Przemysł energetyczny jest sektorem o ogromnym znaczeniu dla gospodarki i życia społecznego. Życie człowieka wydaje się niemożliwe bez stałych dostaw energii (ogrzewanie, oświetlenie). Energia jest również podstawą rozwoju gospodarki, służy też innym sektorom, którymi są np. transport, rolnictwo, usługi. Energetyka wykorzystuje te surowce i zasoby środowiska naturalnego, które są szczególnie narażone na wyczerpanie. Dlatego bardzo istotne jest, by w działalność związaną z sektorem energii wdrażać zasady zrównoważonego rozwoju i poszukiwać nowych, alternatywnych źródeł energii, głównie poprzez wykorzystanie odnawialnych zasobów środowiska.

Według Ustawy o odnawialnych źródłach energii są nimi:

[...] odnawialne, niekopalne źródła energii obejmujące energię wiatru, energię promieniowania słonecznego, energię aerotermalną, energię geotermalną, energię hydrotermalną, hydroenergię, energię fal, prądów i pływów morskich, energię otrzymywaną z biomasy, biogazu, biogazu rolniczego oraz z biopłynów².

Wykorzystanie tych zasobów oraz inwestycje w innowacyjne rozwiązania i technologie w obszarze energii odnawialnej stają się coraz bardziej popularne i doceniane. Na przykład energia słoneczna i wiatrowa jest intensywnie wykorzystywana w krajach Europy Południowej leżących u wybrzeży, np. we Włoszech czy Hiszpanii. Państwa te mają przewagę w tym aspekcie ze względu na korzystne

${ }^{1}$ Nasza wspólna przyszłość. Raport Światowej Komisji do Spraw Środowiska i Rozwoju, przeł. U. Grzelońska, E. Kolanowska, PWE, Warszawa 1991, s. 71.

${ }^{2}$ Ustawa z dnia 20 lutego 2015 r. o odnawialnych źródłach energii, Dz.U. 2015, poz. 478. 
warunki wynikające z położenia geograficznego i naturalnych cech klimatu. Inwestycje w energię odnawialną są odpowiedzią na wymagania unijnej polityki klimatycznej. Wpływ na rozwój tej gałęzi ma także wzrost cen surowców energetycznych, trudno dostępne surowce krajowe oraz względy środowiskowe. Warto dodać, że mimo wszystkich pozytywów, świadomość społeczeństwa z korzyści wdrażania OZE jest dość niska. Jest to poniekąd wyzwanie dla władz, które powinny przeprowadzać kampanie edukacyjne w zakresie energii odnawialnej zarówno wśród dorosłych, jak i wśród dzieci oraz młodzieży.

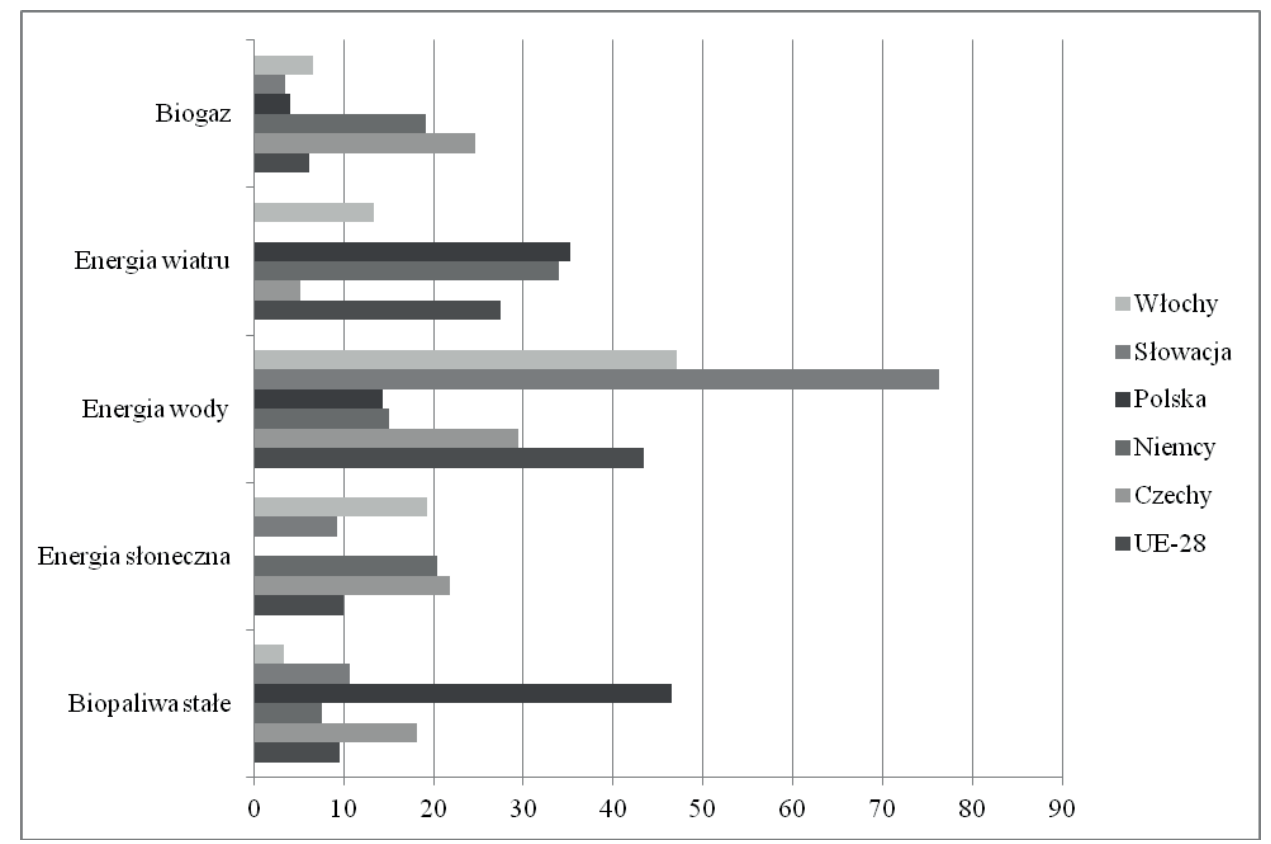

Wykres 1. Struktura produkcji energii elektrycznej z wybranych odnawialnych nośników energii $w$ wybranych krajach UE, 2013 rok

Źródło: opracowanie własne na podstawie: Energia ze źródeł odnawialnych w 2014 r. Informacje i opracowania statystyczne, GUS, Warszawa 2015, s. 27.

Wykres 1 przedstawia procentową strukturę produkcji energii elektrycznej z wybranych odnawialnych nośników energii w wytypowanych krajach Unii Europejskiej w 2013 roku. Biorąc pod uwagę kraje UE ogółem, największy udział w produkcji ma energia wody $(43,4 \%)$, następnie energia wiatru $(27,5 \%)$ i kolejno: energia słońca (10\%), biopaliwa stałe $(9,5 \%)$ i biogaz (6,2\%). Spośród wybranych państw Polska wyróżnia się w produkcji energii elektrycznej z biopaliw stałych $(46,5 \%)$, a także energii wiatru (35,2\%). 


\section{Korzyści i koszty z użytkowania OZE}

Korzyści płynące z inwestowania w OZE można podzielić na korzyści ekonomiczne, społeczne, a także środowiskowe. $Z$ ekonomicznego punktu widzenia można wymienić m.in. następujące profity: zmniejszenie importu paliw, zwiększenie bezpieczeństwa energetycznego kraju, rozwój infrastruktury oraz poprawa bilansu handlowego regionu wykorzystującego OZE, częściowe uniezależnienie od konwencjonalnych źródeł energii, lepsze zaopatrzenie w energię terenów słabo rozwiniętych pod względem infrastruktury, a także gospodarcza aktywizacja społeczności lokalnych. Ponadto do korzyści ekonomicznych zalicza się również niższe koszty wytwarzania energii (cieplnej), możliwość uzyskania wsparcia w postaci środków Unii Europejskiej przeznaczonych na działania proekologiczne czy także promocję regionu jako proekologicznego i innowacyjnego ${ }^{3}$.

Do głównych korzyści społecznych z inwestowania w OZE należy tworzenie nowych miejsc pracy. Szacuje się, że rynek odnawialnych źródeł energii tworzy więcej miejsc pracy niż energetyka konwencjonalna. Zaznacza się przy tym, że rozwój energii odnawialnej wpływa szczególnie korzystnie na obszary wiejskie, które charakteryzują się największym bezrobociem. Rozwój wsi pod tym względem może ograniczyć również migrację ludności do miast.

Do korzyści środowiskowych płynących z wykorzystywania odnawialnych źródeł energii zalicza się natomiast przede wszystkim spowolnienie eksploatacji zasobów nieodnawialnych oraz wzrost bezpieczeństwa energetycznego. Inwestycje w OZE przyczyniają się również do zmniejszenia emisji dwutlenku węgla, prowadzącej do powstawania efektu cieplarnianego. Tym samym mają wpływ na poprawę sytuacji środowiskowej oraz ograniczenie i zahamowanie postępujących zmian klimatycznych.

Mimo wielu korzyści, jakie niosą za sobą inwestycje w energię odnawialną, trzeba również pamiętać, że istnieją wady i koszty rozwoju OZE. W przypadku farm wiatrowych mówi się w szczególności o zagrożeniu dla ptaków - przede wszystkim zwiększa się ich śmiertelność z powodu zderzeń z wiatrakami, poza tym bardzo często farmy wiatrakowe stanowią barierę, która wymusza zmiany tras przelotów lub powoduje utratę siedlisk, lęgowisk bądź żerowisk poprzez zmianę terenu i ich środowiska naturalnego ${ }^{4}$. Farmy wiatrakowe mają również duży wpływ na ludność mieszkającą w pobliżu: są źródłem hałasu i często zaburzają estetykę krajobrazu. Przy instalacji paneli słonecznych wpływ na środowisko i społeczeństwo jest mniejszy. W przypadku energii wiatru, jak i słońca ważne są odpowiednie warunki klimatyczne. Miejsce, w którym zostaną wybudowane dane instalacje,

${ }^{3}$ http://www.polskieradio.pl/42/3167/Artykul/1119367,Energia-odnawialna-korzysci-z-OZE-nie-tylko-dla-srodowiska-ale-i-naszych-portfeli (dostęp: 20.07.2016).

${ }^{4}$ A. Wuczyński, Wplyw farm wiatrowych na ptaki. Rodzaje oddziaływań, ich znaczenie dla populacji ptasich i praktyka badań w Polsce, „Notatki Ornitologiczne” 2009, z. 50, s. 207. 
musi wyróżniać się odpowiednim nasłonecznieniem, w przypadku energii słońca, oraz odpowiednią siłą wiatru i liczbą dni wietrznych w ciągu roku, w przypadku energii wiatru. Wysokie koszty związane są również z samą inwestycją w zakup i odpowiednie zainstalowanie paneli lub wiatraków. Panele słoneczne powinny być ustawione pod dobrym kątem, tak aby czas i powierzchnia pochłaniania promieni słonecznych były jak najdłuższe. Wiatraki zaś powinny mieć wymierzoną wysokość - ani zbyt niskie, ani zbyt wysokie, tak by były jak najbardziej opłacalne. Należy pamiętać, że okres zwrotu inwestycji w energię odnawialną może być stosunkowo długi i może zależeć od często zmieniających się warunków naturalnych. Kolejnym ryzykiem jest także prawdopodobieństwo zmiany prawodawstwa w zakresie wykorzystywania odnawialnych źródeł energii, np. wprowadzenie podatków, opłat.

\section{OZE jako integralna część zarządzania w firmie}

W perspektywie obecnej sytuacji, kiedy rynki stają się coraz bardziej konkurencyjne, wiele firm szuka sposobu na wyróżnienie się na tle swoich konkurentów. Bardzo istotne jest posiadanie przewagi konkurencyjnej, co często jest miernikiem powodzenia działalności gospodarczej. Warto przy tym zwrócić uwagę na to, iż cena nie jest już jedynym czynnikiem mającym wpływ na wybór konsumentów. Coraz częściej cechą decydującą staje się jakość, a także sposób zarządzania firmą, jej wpływ na środowisko naturalne oraz społeczeństwo. Nie bez znaczenia wydaje się tu koncepcja społecznej odpowiedzialności biznesu (CSR) oparta na zrównoważonym rozwoju. Poza maksymalizacją zysku uwzględnia ona również aspekty społeczne, środowiskowe i etyczne funkcjonowania danego przedsiębiorstwa. Komisja Europejska definiuje CSR jako: „odpowiedzialność przedsiębiorstw za ich wpływ na społeczeństwo"s. Taką szeroką perspektywę wdraża się na wszystkich poziomach zarządzania firmą. Zaczynając od kadr menedżerskich, przez pracowników, aż po dostawców, społeczności lokalne i środowisko przyrodnicze, w którym oddziałuje dana firma i z którego korzysta. Zaangażowanie przedsiębiorstwa w działania dotyczące rozwoju odnawialnych źródeł energii idealnie wpisuje się w koncepcję społecznie odpowiedzialnego zarządzania. Dla wielu konsumentów posiadanie strategii CSR przez przedsiębiorstwo i jego pozytywny wpływ na środowisko naturalne mają ogromne znaczenie. Jest to jeden ze sposobów, w jaki firma może budować swoją przewagę konkurencyjną. Warto zaznaczyć, że takie podejście wpływa pozytywnie na całe otoczenie firmy (ludzi i środowisko przyrodnicze), a także buduje pozytywną i jasną pozycję firmy na rynku.

W związku z ideą społecznej odpowiedzialności biznesu wiele przedsiębiorstw podejmuje działania mające na celu poprawę jakości środowiska

${ }^{5}$ Komisja Europejska, Odnowiona strategia UE na lata 2011-2014 dotyczaca społecznej odpowiedzialności przedsiębiorstw, $\operatorname{KOM(2011)~681,~wersja~ostateczna,~Bruksela~2011,~s.~} 7$. 
przyrodniczego bezinteresownie i nie zawsze przez wzgląd na jej podstawową działalność. Poza korzyściami wizerunkowymi i pozytywnym oddziaływaniem na środowisko przyrodnicze, zyskuje wtedy również profity ekonomiczne. Korzystanie z energii odnawialnej oznacza niwelowanie negatywnego wpływu na otoczenie, ale również oszczędności. Zaś inwestycja w pozyskiwanie energii z odnawialnych źródeł może przyczynić się do osiągnięcia częściowej lub całkowitej niezależności energetycznej przez daną firmę.

Przykładem firmy prowadzącej swoją działalność według takiego modelu jest IKEA. Firma, jako producent i sprzedawca mebli oraz artykułów dekoracyjnych, zwraca szczególną uwagę na zasoby środowiska, które wykorzystuje. IKEA znajduje się także w rankingu odpowiedzialnych firm i plasuje się na 43. pozycji wśród takich firm w Polsce ${ }^{6}$. Do społecznie odpowiedzialnych działań w obszarze środowiska w IKEA należą m.in.: kontrola pochodzenia drewna oraz bawełny, których używa się do produkcji mebli i materiałów, promocja odpowiedzialnej gospodarki wodnej w całym łańcuchu dostaw w trosce o jej jakość, a także zużywaną ilość. Poza tym, jako firma przyjazna środowisku, IKEA kieruje się hasłem: „więcej z mniej”, co ma wyraźne odzwierciedlenie w zagospodarowaniu odpadami i recyklingu. Zaś w restauracjach i sklepikach szwedzkich w IKEA można zakupić wiele produktów żywnościowych pochodzących ze zrównoważonych źródeł, posiadających certyfikaty, np. kawa z certyfikatem UTZ, gwarantującym standardy zrównoważonego rolnictwa i sprawiedliwe warunki dla pracowników. Największe zainteresowanie przykuwa gospodarowanie energią przez IKEA. Wykorzystuje się energię z odnawialnych źródeł energii, pochodzącą z paneli słonecznych zainstalowanych na dachach budynków, sklepów firmy, a także z farm wiatrowych należących do IKEA. Szczególną uwagę należy zwrócić na to, iż poza korzystaniem z niekonwencjonalnych źródeł energii, przywiązuje się dużą wagę do efektywności energetycznej budynków. Oznacza to, iż ważny jest rodzaj energii, ale także jej ilość. IKEA jest firmą, która w szczególny sposób dba o rozwój zrównoważonego rozwoju, nie tylko w swojej działalności, ale również wśród klientów. Dlatego właśnie produkty oferowane przez firmę mają pokazywać rozwiązania pozwalające na oszczędność energii czy zmniejszenie ilości odpadów. IKEA dba również o swoich pracowników, a także ludzi i społeczności mające styczność z firmą na jakimkolwiek etapie produkcji.

\section{Wykorzystanie OZE przez IKEA}

IKEA chętnie przedstawia dokumenty oraz strategie zawierające jej stanowiska odnośnie do dbania o środowisko naturalne i cele, jakie wyznacza sobie jako firma w tym obszarze. W publikacjach prezentowanych przez IKEA

${ }^{6}$ IX Ranking odpowiedzialnych firm 2015, „Dziennik Gazeta Prawna”, 22.04.2015, s. 4. 
dotyczących dbania o klimat i wykorzystywania energii można znaleźć informacje o dotychczasowych osiągnięciach w tym zakresie. Firma deklaruje m.in.: oszczędności w wysokości $40 \mathrm{mln}$ euro w sklepach oraz centrach dystrybucji, wynikających tylko z wydajności energetycznej, przeznaczenie 1,5 mld euro na inwestycje w energię odnawialną do 2015 roku, a także 650 tys. paneli słonecznych zainstalowanych dotychczas na budynkach IKEA oraz 206 turbin wiatrowych w $10 \mathrm{krajach}^{7}$.

W swojej strategii People \& Planet Positive na 2020 rok firma deklaruje dążenie do niezależności energetycznej poprzez bycie liderem w zakresie pozyskiwania energii ze źródeł odnawialnych. Prowadzi to do wyznaczenia konkretnego celu, którym jest produkowanie takiej ilości energii, jakiej firma potrzebuje do konsumpcji przy swoich działaniach (do 2020 roku), zaś do 2015 roku produkować co najmniej $70 \%$ zużycia. Zaznacza się także podejmowanie działań nad zwiększeniem wydajności energetycznej budynków ${ }^{8}$.

By osiągnąć wyznaczone cele, podjęto liczne działania. Jedno z nich polegało na zachęcaniu dostawców do zainicjowania poczynań na rzecz efektywności energetycznej. Została podjęta współpraca z dostawcami i wprowadzono program „Suppliers Go Renewable”. Celem tego projektu, realizowanego w 2013 roku, było zwiększenie zużycia energii odnawialnej w łańcuchu dostaw. Kolejnym istotnym zadaniem mającym się przyczynić do osiągnięcia wyznaczonych celów jest tworzenie odnawialnych rozwiązań energetycznych dla budynków, infrastruktury oraz transportu. Celem szczegółowym było zwiększenie wydajności energetycznej o $20 \%$ we własnych operacjach, a także zachęcenie dostawców do osiągnięcia tego samego celu do 2017 roku. Następne wyzwanie to zmniejszenie emisji dwutlenku węgla do 2015 roku w ramach własnej działalności o 50\%, zaś u dostawców o $20 \%$. Wzięto także pod uwagę emisję $\mathrm{CO}_{2}$ w transporcie i postanowiono do 2016 roku zmniejszyć jego emisję w transporcie i dostawach do domu klienta o $20 \%{ }^{9}$.

Ponadto jako ogólny cel IKEA deklaruje rozwój przez inwestowanie w odnawialne źródła energii, wydajność energetyczną, modernizację oraz rozbudowę sklepów, niską emisję $\mathrm{CO}_{2}$ w transporcie. Ogłasza także, że będzie brać pod uwagę zrównoważony rozwój jako podstawę swoich decyzji inwestycyjnych, takich jak rozwój transportu oraz nieruchomości. Firma zobowiązuje się również do publicznego raportowania postępów.

W dokumencie IKEA Group FY15 Sustainability Report podsumowana jest dotychczasowa realizacja wyznaczonych celów. W obszarze energii

${ }^{7} \mathrm{http} / / \mathrm{www} . \mathrm{ikea} . \mathrm{com} / \mathrm{ms} / \mathrm{pl}$ PL/pdf/reports-downloads/IKEA_Group_position_on_climate and_energy.pdf (dostęp: 20.07.2016).

${ }^{8}$ People \& Planet Positive IKEA Group Sustainability Strategy for 2020, IKEA Group, 2012, s. 9 .

9 Ibidem, s. 14. 
odnawialnej niestety żaden z nich nie został osiągnięty w pełni. Na przykład szacowano produkcję energii odnawialnej na poziomie 70\% zapotrzebowania, zaś stan na 2015 rok wynosi 53\% konsumowanej energii. Inny przykład to plan osiągnięcia o $20 \%$ większej wydajności energetycznej, zaś w porównaniu z 2010 rokiem wydajność energetyczna w sklepach wyniosła 14,6\%, w centrach dystrybucji $26,8 \%{ }^{10}$.

\section{Przykłady działań w IKEA na rzecz efektywności energetycznej}

Aby osiągnąć wyznaczone cele, firma musi się skupić na konkretnych działaniach, by ambitne plany mogły stać się rzeczywistością. Chcąc wypracować planowany poziom efektywności energetycznej i zużycia energii odnawialnej, IKEA podejmuje aktywność w tym zakresie na każdym etapie procesu produkcyjnego. Większość działań dotyczy zaplecza techniczno-technologicznego i opiera się na ścisłej współpracy z dostawcami i firmami, z którymi kooperuje. Na przykład w ramach współpracy z Iveco Trucks oraz z Cryogas testom poddawane są ciężarówki napędzane metanem płynnym LNG. Celem jest zbadanie, czy istnieje możliwość uniezależnienia się od ropy, a także wykazanie, jak wysokie mogą być oszczędności, redukcja $\mathrm{CO}_{2}$ czy też hałasu. W kwestii transportu IKEA prowadzi również kodeks etyczny dla swoich przewoźników. Kodeks IWAY („IKEA Way on Purchasing Products, Materials and Services") zakłada m.in.: plan redukcji $\mathrm{CO}_{2} \mathrm{w}$ firmach transportowych, monitoring zużycia paliwa we flocie zaopatrującej IKEA czy też normy emisji spalin nieprzekraczające poziomu 10-letnich samochodów. Na podstawie takich danych dokonuje się wyboru firm mających świadczyć usługi dla IKEA. Kolejny przykład działania to wykorzystywanie strat ciepła poprzez zainstalowany system rekuperacji ciepła ze sprężarek. Ciepło to jest używane do ogrzewania jednej z hal produkcyjnych. Innym działaniem podjętym przez IKEA mającym na celu wzrost wydajności energetycznej jest zastosowanie inteligentnego oświetlenia. Wprowadza się oświetlenie LED, które jest bardziej wydajne i oszczędne. Intensywność generowanego światła jest automatycznie dostosowywana do pory dnia, a także dopływu naturalnego światła. Następnym przykładem jest modernizacja kotłowni i zmiana opału z olejowego na granulat drzewny. Zaletą tej modyfikacji jest wysoka dostępność surowca, jakim jest pellet drzewny, jego relatywnie niska cena, a także względy środowiskowe. Stosowanie opału drzewnego generuje „neutralny węgiel”, czyli taki, który krąży w przyrodzie i bierze udział w procesach życiowych, zaś jego spalanie nie emituje gazów cieplarnianych ${ }^{11}$.

${ }^{10}$ IKEA Group FY15, Sustainability Report, IKEA Group, s. 36.

${ }^{11} \mathrm{http} / /$ www.ikea.com/ms/pl_PL/img/vitality/energia_dobre_przyklady_IKEA_dostawcy_ PL.pdf (dostęp: 20.07.2016). 
Istnieje więcej przykładów działań mających na celu zwiększenie wydajności energetycznej IKEA w Polsce. Dotyczą one m.in.: falowników, wentylatorów, użytkowania baterii akumulatorowych, wymiany wózków widłowych, sprężarek, wtryskarek, modułów fotowoltaicznych, mat termoizolacyjnych, pomp ciepła czy układów chłodzenia.

\section{Podsumowanie i wnioski}

Rozwój odnawialnych źródeł energii jest odpowiedzią na narastające globalne problemy środowiskowe i - co za tym idzie - coraz bardziej restrykcyjną politykę w zakresie zmian klimatycznych i środowiska naturalnego. W związku z tym inwestycje w pozyskiwanie energii ze źródeł odnawialnych stają się coraz bardziej powszechne i perspektywiczne. Najpopularniejszymi odnawialnymi źródłami energii wykorzystywanymi w Unii Europejskiej są energia wody, wiatru oraz słońca. W Polsce zaś największą popularnością cieszy się energia z biopaliw. Inwestycje w OZE niosą za sobą wiele pozytywnych aspektów (tworzenie nowych miejsc pracy, oszczędności, wydajność i niezależność energetyczna), ale wiążą się również z kosztami (duże nakłady na inwestycje i ryzyko inwestycyjne, zaburzenie estetyki krajobrazu).

Wiele firm podejmuje działalność w obszarze OZE, niezależnie od profilu swojej działalności. Aktywność taka jest powiązana $\mathrm{z}$ wdrażaniem społecznie odpowiedzialnego zarządzania. IKEA jest przykładem firmy, która od wielu lat prowadzi strategię CSR i w ramach tej działalności zajmuje się inwestycjami w odnawialne źródła energii. Takie podejście zapewnia firmie nie tylko dodatni wpływ na środowisko, ale również zyski ekonomiczne, tworzy pozytywny wizerunek firmy na rynku i gwarantuje przewagę konkurencyjną. IKEA posiada jasno sprecyzowane cele w zakresie osiągnięcia niezależności i poprawy wydajności energetycznej. Na bieżąco monitoruje działania i raportuje swoje postępy w tym obszarze. By sprostać podjętym wyzwaniom, firma nadzoruje współpracę z dostawcami oraz firmami kooperującymi. Podejmuje także konkretne działania, np. wprowadza oświetlenie LED czy też modernizuje kotłownie oraz inne urządzenia, których działanie ma wpływ na pobór energii elektrycznej.

Można stwierdzić, że OZE mogą stać się integralną częścią biznesu i w ten sposób przyczynić do zwiększenia bilansu ekonomicznego firmy, jednocześnie generując pozytywny wpływ na środowisko naturalne. Inwestycje w odnawialne źródła energii przez firmy takie jak IKEA przyczyniają się również do zwiększania świadomości ekologicznej wśród społeczeństwa. 


\section{Bibliografia}

IX Ranking odpowiedzialnych firm 2015, „Dziennik Gazeta Prawna”, 22.04.2015.

IKEA Group FY15, Sustainability Report, IKEA Group.

Komisja Europejska, Odnowiona strategia UE na lata 2011-2014 dotyczaca społecznej odpowiedzialności przedsiębiorstw, $\mathrm{KOM}(2011)$ 681, wersja ostateczna, Bruksela 2011.

Nasza wspólna przyszłość. Raport Światowej Komisji do Spraw Środowiska i Rozwoju, przeł. U. Grzelońska, E. Kolanowska, PWE, Warszawa 1991.

People \& Planet Positive IKEA Group Sustainability Strategy for 2020, IKEA Group, 2012.

Rak J., Kalda G., Innowacyjne metody wykorzystania źródet energii słonecznej, Mikołajew 2007, Prace Naukowe Mikołajewskiego Narodowego Uniwersytetu, t. 73.

Ustawa z dnia 20 lutego 2015 r. o odnawialnych źródłach energii, Dz.U. 2015, poz. 478.

Wuczyński A., Wpływ farm wiatrowych na ptaki. Rodzaje oddziaływań, ich znaczenie dla populacji ptasich i praktyka badań w Polsce, „Notatki Ornitologiczne” 2009, z. 50, s. 206-227.

Zimny J., Odnawialne źródła energii w budownictwie niskoenergetycznym, Polska Geotermalna Asocjacja, Akademia Górniczo-Hutnicza, Wydawnictwa Naukowo-Techniczne, KrakówWarszawa 2010.

http://www.ikea.com (dostęp: 10.07.2015).

http://www.polskieradio.pl (dostęp: 10.07.2015).

\section{Streszczenie}

Celem artykułu jest przedstawienie znaczenia odnawialnych źródeł energii we współczesnej gospodarce, a także pokazanie, że inwestycje w energię niekonwencjonalną mogą się stać integralną częścią biznesu. Ukazane są główne korzyści, ale również i koszty wynikające z użytkowania odnawialnych źródeł energii. Artykuł przedstawia także wielkości produkcji energii elektrycznej z odnawialnych źródeł w Unii Europejskiej oraz wybranych krajach. Na przykładzie firmy IKEA pokazane jest, że wykorzystanie odnawialnych źródeł energii może się stać częścią zarządzania w firmie, co wpisuje się również w koncepcję społecznej odpowiedzialności biznesu. Praca przedstawia cele i działania firmy w drodze do osiągnięcia niezależności energetycznej i zwiększania efektywności w tym zakresie.

Słowa kluczowe: odnawialne źródła energii, społeczna odpowiedzialność biznesu

Numer klasyfikacji JEL: M20, M14, O13, Q20, Q25 